\title{
Randomness and Providence in Christian Thought
}

\author{
Karen R. Zwier
}

\subsection{Goals and Orientation}

In this chapter, I will show that the problem of randomness and providence is not a new one that has only become apparent in the modern era, with Christian thinkers scrambling to contort theology to accommodate. Rather, there is a long history of sophisticated thought in response to this problem, and it can be called upon to address the problem in its modern scientific variant.

The chapter will be organized as follows. In Sect. 9.2, I will give a basic overview of Christian belief. The overview is sweeping and is intended mostly for those who are unfamiliar. Section 9.3 covers the concept of divine providence in Christian thought, concentrating on relevant pieces of Christian scripture and passages from some of the Christian Fathers. In Sect. 9.4, I cover, in historical fashion, how Christians at various points in

K. R. Zwier (四)

Des Moines, IA, USA

(C) The Author(s) 2022

K. J. Clark, J. Koperski (eds.), Abrahamic Reflections on

Randomness and Providence, https://doi.org/10.1007/978-3-030-75797-7_9 
history have grappled with the question of randomness in relation to God's providence. Finally, in Sect. 9.5, I propose my own way of thinking about randomness and providence.

\subsection{INTRODUCTION TO CHRISTIANITY}

In order to address the relationship between providence and randomness within Christianity, I first need to give an introduction to Christianity. I can only make an attempt at an introduction, and it will necessarily be brief. There are many things I won't be able to mention or explain, but I'll do my best to lay out the "fundamentals" of Christianity in a way that will hopefully illuminate some of the core ideas that will matter for Christian views on providence and randomness.

This introduction (and the entire chapter, for that matter) will be colored by my own perspective as a Christian of a particular denomination. I am a Catholic Christian. I'll do my best to represent the breadth and diversity of Christianity, but my Catholic perspective will at times influence the way I present things here. One way in which this influence will come out is in my emphasis on history. I will be employing a broadly historical approach here, and that is because I tend to see theology and history as strongly tied to one another. The historical continuity of Christian beliefs and institutions is of great importance (and comfort) to me. I ground my beliefs in a tradition and a community. To separate tradition and community from Christian theology removes, for me, one of the main reasons to take it seriously.

\subsubsection{The Person of Jesus}

The Christian faith centers on Jesus of Nazareth, who lived in the first few decades of the Common Era. The Common Era is, of course, dated roughly to the time of his birth, which is why we have the abbreviations "B.C." (Before Christ) and “A.D." (Anno Domini, Year of our Lord) (though his actual birth may have been a few years B.C.).

Jesus was born into a devout Jewish family in Nazareth in the region of Galilee in Northern Israel, which had its own distinctive political and religious context. The separation of the tribes of Israel had left Galilee geographically removed from Judea and, most importantly, Jerusalem. As a devout Jew, Jesus had something of an insider status, but as a Galilean, he would have also been regarded as an outsider by Judeans. 
Jesus lived a quiet life until, at around 30 years of age, he began traveling around both Galilee and Judea, preaching publicly and healing the sick. The Jewish faith served as the background of his preaching: one God who is Creator, God's special covenant with the Jews as his chosen people, and the Torah as a set of sacred moral precepts. But there were also distinctively new elements to his preaching which went beyond literalist readings of the Torah and called for a higher standard of morality. For example, he condemned divorce, discouraged "eye for an eye" justice, and broke Sabbath rules in order to heal.

One of Jesus' central messages was the coming of God's kingdom. The meaning of this message appears to have been just as mysterious and ambiguous to Jesus' contemporaries as it sounds to us today. Those who interpreted him as a political revolutionary who would free the Jews from Roman rule would later be quite disappointed. It appears to have meant, for Jesus and his followers, that God was present and active in the world right then and there, and that God was calling his followers into a new kind of relationship with him.

Jesus' teachings earned him the consternation of some of the Jewish elite, who eventually brought him to the Roman authorities who had him executed by crucifixion. He was crucified on a Friday, right before the Passover feast began. On Sunday morning (after Passover had ended), when some of his followers went to his tomb to anoint his body, they found the tomb empty. Jesus later appeared to his disciples on a few occasions, in bodily form. The death and resurrection of Jesus became the focal point of celebration for the earliest Christians.

\subsubsection{Early Christianity}

The story of the first few decades and centuries of Christianity is a story of gradual self-definition. The earliest Christians - those who had known Jesus and walked with him-were deeply impacted by their experiences. These close followers carried with them a conviction that Jesus was inexpressibly different from ordinary human beings. They believed that he was the Christ, the messiah that God had promised to the Jews. But controversies arose, and these controversies led to efforts to further define Christian belief. What we inherit in our modern concept of Christianity is a result of early councils in which the members of the church sought to define who they were and what they believed. 
Jesus' followers began as a community in Jerusalem and began to spread to other cities across the Roman Empire. In the beginning nearly all were Jews, seeing themselves as a sect within Judaism. But increasing numbers of non-Jews (called Gentiles) began to convert to the way of Jesus, which led to their first big controversy: to what extent was the way of Jesus linked to the ways of the Jewish faith? Specifically, did the Gentile converts have to steep themselves in the Jewish traditions and observe Jewish practices (e.g., circumcision, dietary regulations)?

After a council in Jerusalem, it was decided officially that Gentile Christians were not lesser than Jewish Christians. In fact, not only were the Gentile followers relieved of obeying Jewish law, but no Christianeven a Jewish Christian-was required to obey Jewish law in its entirety. The council directed followers to merely abide by certain minimal rules (i.e., avoiding unchastity, avoiding idolatry, and abstaining from blood). Jesus' death and resurrection carried redemptive power and the forgiveness of sins, and as followers of Jesus, obedience to the Jewish law was not considered redemptive. Jesus the Messiah come into the world meant a transformation in the way that God's people were called to live. Jesus' death was the one and final sacrifice, and his resurrection signaled the birth of a new era of life with God. Jesus offered a new "law"-a law of the spirit. Jews and Gentiles alike were elevated to status as children of God.

The Jerusalem council was the first major self-defining decision, and there were more to come. Amid these early controversies, it's important to note that there was no accepted set of authoritative texts (later called the canon) of Christian scripture other than the Jewish scriptures. (The first written gospel, for instance, is thought to be Mark, which was written shortly before the fall of Jerusalem in 70 A.D.) The churches throughout the Roman Empire communicated primarily through letters and traveling missionaries and representatives. These letters, which began to take on a special importance, were read at church gatherings. A special importance was assigned to the writings of those who had the status of Apostle (those who has been personally commissioned by Jesus). The canon of Christian scriptures (consisting mostly of these letters) came into place only gradually. The set of scriptures that we now call the "New Testament" was mostly settled by the early decades of the second century, with the definitive finalization around 380/390 A.D.

Structures of Christian authority also evolved gradually from the early days in Jerusalem. Apostolic succession (an unbroken chain of authority passed down from the apostles and transmitted by the laying on of hands) marked those who had the special status of bishop. Bishops were 
effectively "custodians" of the truth of the Christian faith, a duty passed on to them by the apostles.

I've now covered two of the three main doctrinal loci of the early Christian faith: the set of writings that would later form the canon of the New Testament and the teaching of the bishops. The third source of early doctrine was presented in various creeds. These creeds summarized the teaching of the apostles and were taught to followers of Jesus. Although these creeds varied slightly by region, they were in substance quite similar to the modern-day Apostles' Creed.

The central elements of early Christian doctrine still define core Christian belief today. I'll briefly describe three core doctrines that will shape some of my discussion below. These are: the incarnation, the Trinity, and salvation by Christ.

\section{The Incarnation}

Belief in the incarnation (enfleshment) is the belief that God became human in Jesus Christ. Although there was great controversy over the nature of Jesus, the accepted view is that Jesus is both fully human and fully divine-two natures (human and divine) united in one person. $\mathrm{He}$ existed as a divine person (the second person of the Trinity-see below) from all eternity, but at the moment of the incarnation, he took on a human nature as well. "And the Word became flesh and lived among us, and we have seen his glory, the glory as of a father's only son, full of grace and truth" (John 1:14). The incarnation, the revealing of God to humanity, is particularly significant against the backdrop of Jewish history. God had attempted to reveal himself to his people by a series of covenants, by law, and by prophets. But none of these could be as definitive (and effective) as God's own coming into the world. Is the incarnation mysterious? Absolutely. But "God so loved the world" (John 3:16) that he did the impossible - he bridged the gap between human and divine by becoming human himself, in order to reveal himself to humanity.

\section{The Trinity}

As if the incarnation were not mysterious enough, Christians also believe that God is a Trinity. God is one God in three persons: Father, Son, and Holy Spirit. Christianity sees itself as an emphatically monotheistic continuation of Judaism, but also carries with it the belief that Jesus, as God incarnate, revealed previously hidden aspects of the inner life of God. Christians understand each of these-Father, Son, and Spirit - as a distinct person of the Trinity, perfectly united in an eternal exchange of love. 


\section{Salvation by Christ}

Humans (and the world as a whole) are fallen. The story of Adam and Eve's temptation and fall in the Garden of Eden (Genesis 3) is interpreted in a variety of ways by Christians, but the fundamental truth it communicates is that humans have an inherent tendency toward sin. Christians share the belief that Christ's death and resurrection effect our salvation from $\sin$. His death on the cross is interpreted in the New Testament as the fulfillment of the tradition of sacrifices under Jewish law. As God-Man, he is uniquely capable of serving as the final and eternal high priest offering himself up in sacrifice to God (see Hebrews 7:11-28). His resurrection affirms his victory over sin and evil and the beginning of God's new creation (see Isaiah 65:17).

The details of how Christian salvation works are matters of substantial disagreement among Christians and, regrettably, a source of many divisions. Some Christians believe that salvation is obtained solely by faith in Jesus; others by a combination of faith and good works. Some believe that salvation requires explicit faith in Christ, while others hold that it has a more counterfactual character (i.e., salvation is extended to those persons who would accept Christ's offer of salvation if they were to have a deep encounter with Jesus and his teachings). Some Christians believe that salvation is attained once and for all by one's statement of faith; others believe that salvation is a lifelong process. Some Christians believe that Christ's sacrifice is a payment of the debt that humanity has incurred through sin, while others believe that Christ's sacrifice is a victory over the power of sin that offers a transformative power to Christians. And there is a variety of combinations of the above views.

I will say something about my personal stance on Christian salvation, because it is operative in my thoughts on providence and randomness. I believe that salvation is a gradual and lifelong process of transformation. While Christ's sacrifice makes such transformation possible, it also requires faith and participation on the part of the Christian herself.

\subsection{Christian Thinking on Divine Providence}

God's providence has been of central theological concern from the earliest moments of Christianity. Both the New Testament authors and a group of early church leaders (called "church fathers") concerned themselves with the nature of God's providence, as well as the theological problems and 
puzzles that arise when God's providence is affirmed. These teachings developed over time into a set of robust philosophical positions.

\subsubsection{Providence in Scripture}

The first and most obvious place to examine the Christian understanding of providence is the Bible. Consider the following passage from Psalm 104:

10. You make springs gush forth in the valleys; they flow between the hills,

11. giving drink to every wild animal; the wild donkeys quench their thirst.

12. By the streams the birds of the air have their habitation; they sing among the branches.

13. From your lofty abode you water the mountains; the earth is satisfied with the fruit of your work.

14. You cause the grass to grow for the cattle, and plants for people to use, to bring forth food from the earth,

15. and wine to gladden the human heart, oil to make the face shine, and bread to strengthen the human heart.

16. The trees of the Lord are watered abundantly, the cedars of Lebanon that he planted.

17. In them the birds build their nests; the stork has its home in the fir trees.

18. The high mountains are for the wild goats; the rocks are a refuge for the coneys.

19. You have made the moon to mark the seasons; the sun knows its time for setting.

20. You make darkness, and it is night, when all the animals of the forest come creeping out.

21. The young lions roar for their prey, seeking their food from God.

22. When the sun rises, they withdraw and lie down in their dens.

23. People go out to their work and to their labor until the evening.

This psalm gives a beautiful characterization of what Christians call general providence - the idea that God created the structure of the world in such a 
way that it provides for the well-being of his creatures. The psalm affirms that God has created the world in which we live and that God is both directly and indirectly active in providing for his creatures. On the one hand, he acts directly, making springs gush forth, watering the mountains, planting cedars. On the other hand, he acts indirectly by granting existence and making things what they are, to operate in certain regular patterns, such that the very things of creation provide with regularity. $\mathrm{He}$ causes grass to grow so that the cattle might eat it, plants so that people might use them, trees so that birds might build their nests in them. $\mathrm{He}$ makes the sun and moon to rise and set so that there might be seasons and daily rhythms from which animals take their cues.

The author of the psalm makes these assertions plainly, as if they are in need of no evidence. Although the passage is itself scripture, it claims the clear and straightforward knowability of God's providence. Accordingly, Christians take general providence to be evident in the world itself via "natural revelation," and as such, evident to all people. "Natural revelation" refers to the ways in which God reveals himself in and through the workings of nature (independent of any special revelation, like Scripture). Speaking to the Athenians, St. Paul attributes to them a vague recognition of the Jewish and Christian God, "the God who made the world and everything in it, he who is Lord of heaven and earth ... [who] himself gives to all mortals life and breath and all things. From one ancestor he made all nations to inhabit the whole earth, and he allotted the times of their existence and the boundaries of the places where they would live" (Acts 17:24-26). Elsewhere, in his letter to the Romans, St. Paul affirmed that "what can be known about God is plain to them [those who do not acknowledge God], because God has shown it to them. Ever since the creation of the world his eternal power and divine nature, invisible though they are, have been understood and seen through the things he has made" (Romans 1:19-20).

The Christian scriptures also affirm providence in another sense. Over and above God's providing for his creatures by placing them within an overall structure designed to meet their needs, God also cares and provides for individuals in particular, detailed ways. This distinct type of providence, called special providence, holds that God's care is individualized in the form of plans for each person. Just as God had plans for the nation of Israel (Jeremiah 29:10-11), so he has plans for each person. And these plans are better than we, in our limited state, can possibly imagine: "What 
no eye has seen, nor ear heard, nor the human heart conceived, what God has prepared for those who love him" (1 Cor 2:9; cf. Isaiah 64:4).

God has a special providential care for the quotidian needs of each of his creatures. In the Gospel of Matthew, Jesus says, "Are not two sparrows sold for a penny? Yet not one of them will fall to the ground apart from your Father. And even the hairs of your head are all counted. So do not be afraid; you are of more value than many sparrows" (Matthew 10:29-30). Here we see that God's providence is not merely a general care to provide a structure by which creation is sustained, but extends to the meticulous level of providing for sparrows and counting the hairs on our heads. ${ }^{1}$

Alongside scriptural affirmations of special providence are warnings to not be overly concerned with the needs of the body.

Therefore do not worry, saying, 'What will we eat?' or 'What will we drink?' or 'What will we wear?' For it is the Gentiles who strive for all these things; and indeed your heavenly Father knows that you need all these things. But strive first for the kingdom of God and his righteousness, and all these things will be given to you as well. (Matthew 6:31-33)

There is, therefore, a hierarchy of goods to be expected from God, with eternal spiritual goods being of higher value than the transient goods pertaining only to this life. St. Paul's letters develop a theology in which special providence reaches its highest and purest form as God's grace, which provides for the spiritual needs of humanity. If the ultimate goal and destiny of people is salvation, then the utmost form of providence is that by which God, through grace, grants righteousness and elevates a person to a shared life with him. While the providence that leads toward salvation is extended to all (cf. I Timothy $2: 3-4$ ), it is also particular to each individual (cf. 2 Thessalonians 2:12-13).

Inasmuch as salvation is the highest form of providence, it is the primary concern of God for us, and will sometimes outweigh our specific transient needs. In times when the Christian is afflicted with suffering and may be tempted to think that God does not care, St. Paul entreats them to recall the purpose of God's providence for them:

[S]ince we are justified by faith, we have peace with God through our Lord Jesus Christ, through whom we have obtained access to this grace in which

\footnotetext{
${ }^{1}$ See also: Matt 6:26-34, 7:7-11; Luke 11:5-13; John 16:23.
} 
we stand; and we boast in our hope of sharing the glory of God. And not only that, but we also boast in our sufferings, knowing that suffering produces endurance, and endurance produces character, and character produces hope, and hope does not disappoint us, because God's love has been poured into our hearts through the Holy Spirit that has been given to us. (Romans 5:1-5)

It is through a firm confidence in God's highest form of providence, his love, and his grace, that St. Paul exhorts the Christian to persevere in times of suffering. In such times, God's providence may appear to be absent, but in reality is not.

Who will separate us from the love of Christ? Will affliction, or distress, or persecution, or hunger, or nakedness, or peril, or the sword? For thy sake, says the scripture, we face death at every moment, reckoned no better than sheep marked down for slaughter. Yet in all this we are conquerors, through him who has granted us his love. (Romans 8:35-37)

In light of the scriptural texts above, I propose a third distinct label as we grapple with the Christian understanding of God's providence: redemptive providence. "Redemptive providence," in the case of a human being, denotes God's care for their eternal life and salvation as an individual. More generally, it refers to God's will to transform all of creation:

For the creation waits with eager longing for the revealing of the children of God; for the creation was subjected to futility, not of its own will but by the will of the one who subjected it, in hope that the creation itself will be set free from its bondage to decay and will obtain the freedom of the glory of the children of God. We know that the whole creation has been groaning in labor pains until now; and not only the creation, but we ourselves, who have the first fruits of the Spirit, groan inwardly while we wait for adoption, the redemption of our bodies. (Romans 8:19-23)

Akin to the hierarchy of goods, we might affirm that there is a corresponding hierarchy of providence in which redemption is paramount. That is to say: redemptive providence is the most highly valued form of providence because it is oriented toward the highest good, and it will often outweigh special providence, which is oriented toward more transient goods. Furthermore, special providence will sometimes outweigh general providence, inasmuch as God's care for an individual creature's transient needs 
sometimes outweighs God's care for maintaining the overall structure by which the needs of creatures are ordinarily met. This hierarchy will inform some of the problems and questions we will encounter later.

\subsubsection{Fathers of the Church on Divine Providence}

The term "Christian Fathers" or "Church Fathers" refers to a set of particularly influential and authoritative Christian writers over the first several centuries of Christian history. The exact set of authors is ill-defined; Christian denominations disagree to some extent on which authors are to be included in the list, and whose writings should be emphasized. But despite differing views on the exact body of authors and texts, the need for some kind of category of authoritative early Christian thought is clear. For Christians, the set of Old Testament and New Testament scriptures constitute the revealed word of God. But scripture doesn't always carry its meaning on its face, and it lends itself to a wide variety of theological readings. As the early church faced a variety of controversies and disagreements, a core identity of shared belief and practice emerged and was gradually made explicit through various writings and councils. Thus, the writings of the Church Fathers over this crucial time period of development and definition stand as an important reference point for identifying core Christian beliefs.

Where scripture leaves certain questions about providence unanswered, therefore, we can turn to the fathers for more insight. The scriptural themes noted in the last section-of general providence, special providence, and redemptive providence-are further emphasized and reinforced by the Church Fathers (Fig. 9.1).

General providence is mentioned time and time again by the early Church fathers. Clement, writing around the turn of the second century, explained general providence in the following way:

The heavens are moved by His direction and obey Him in peace. Day and night accomplish the course assigned to them by Him, without hindrance one to another. The sun and the moon and the dancing stars according to His appointment circle in harmony within the bounds assigned to them, without any swerving aside. The earth, bearing fruit in fulfilment of His will at her proper seasons, putteth forth the food that supplieth abundantly both men and beasts and all living things which are thereupon, making no dissension, neither altering anything which $\mathrm{He}$ hath decreed. Moreover, the 


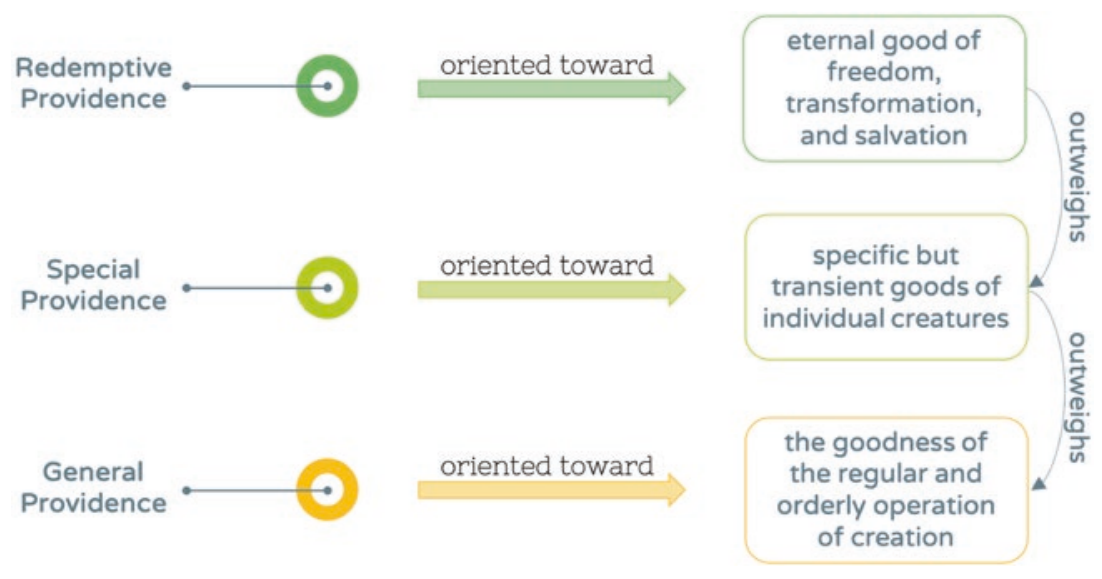

Fig. 9.1 Types of providence

inscrutable depths of the abysses and the unutterable statutes of the nether regions are constrained by the same ordinances. The basin of the boundless sea, gathered together by His workmanship into its reservoirs, passeth not the barriers wherewith it is surrounded; but even as He ordered it, so it doeth. For He said, So far shalt thou come, and thy waves shall be broken within thee. The ocean which is impassable for men, and the worlds beyond it, are directed by the same ordinances of the Master. The seasons of spring and summer and autumn and winter give way in succession one to another in peace. The winds in their several quarters at their proper season fulfil their ministry without disturbance; and the everflowing fountains, created for enjoyment and health, without fail give their breasts which sustain the life for men. Yea, the smallest of living things come together in concord and peace. All these things the great Creator and Master of the universe ordered to be in peace and concord. ${ }^{2}$

Here we see an emphasis on the regularity, rhythms, and laws of creation as directly ordained by God. John Chrysostom, four centuries later, wrote similarly:

[I] fou doubt [that God cares for all things], inquire of the earth, the heavens, the sun, the moon; ask the various irrational beings, the seeds, the

${ }^{2} 1$ Clement 20, from Joseph Barber Lightfoot, tr. The Apostolic Fathers (London, Macmillan and Co., 1898). 
plants, the speechless fish, the rocks, the mountains, the valleys, the hills, the night, the day. For God's providence is as plain as the sun and its rays. In each situation and place, in the wilderness, in inhabited regions and uninhabited, on earth or sea or wherever you might go, you will observe the clear and sufficient, ancient and new, reminders of this providence; voices which speak more clearly than our rational voice and are conveyed from all places, teaching those who are willing to listen about his constant concern. ${ }^{3}$

And Theodoret of Cyrus, writing in the middle of the fifth century:

Consider now at least, if you have not done so before, the nature of visible objects, their position, order, situation, movement, rhythm, harmony, gracefulness, beauty, splendor, utility, charm, variety, diversity, changeability, their regular return to the same place, their permanence in corrupt natures. [...] Behold providence manifested in the heavens and the heavenly bodies, the sun, the moon, and stars. Behold it also in the air and in the clouds, on land and in the sea, and in everything on the earth, in plants, grasses, and seeds; in animals, rational and irrational, footed and winged, swimming, creeping, and amphibian, tame and wild, domesticated and savage. (Theodoret 1988, 13-15)

In these passages, providential care and control of the regularities of creation are taken to be readily apparent. General providence is "plain," something to "behold," and in need of no rational argument or defense. The picture painted is beautiful and poetic.

But general providence poses a set of problems. We might wonder: why does God provide for us in this general way rather than a different general way? Some features of creation seem to be rather indirect or inefficient ways of providing for us. For example, why should God have created a structure in which thunder and lightning accompany the rain, which falls to the earth and waters the plants, so that we might have food? Why should he not instead have created a system in which food spontaneously pops into our hands, or for that matter, why not create our bodies in such a way that they automatically generate their own sustenance? Why this system rather than a better one, in which we are provided for more efficiently or more directly?

${ }^{3}$ Hall, Christopher Alan, tr. (1991). John Chrysostom's 'On Providence': a Translation and Theological Interpretation, p. 193. 
Such questions suggest two objections to the idea of general providence. On the one hand, given that the structure of creation provides for us only in an indirect and inefficient manner, we might be led to think that there is no providence. We might think that these features of the world on which we depend are not the result of a provident God, but rather are products of chance, and it just so happens that we are resourceful beings who make use of them. On the other hand, we might admit that there is a providential design built into creation by God, but given its indirect and inefficient nature, conclude that human beings are not privileged with respect to that providential design. We are provided for, but no more so than God's other creatures. The rain falls equally on all: oceans, rocks, plants, animals, human beings.

These worries were confronted by Origen, a third-century Father, in a response to the philosopher Celsus, a critic of Christianity. Origen identified both of the aforementioned objections to general providence as serious affronts to Christian piety. To believe on the basis of the indirect way in which our needs are met that there is no divine providence is to have a small and selfish view. Why, Origen asks, should we be surprised that human beings are not the only objects of God's care? Why should God not be allowed to create an entire system of care that provides for the needs of all his creatures, without making us doubt his care for us? Should we not be all the more in awe of his providence in light of his care for other creatures, rather than less so? (Origen 1980, bk. IV 75 ).

Yet, for Origen, it is equally an error to focus so much on God's providence with respect to non-human creatures that we cease to believe in his special care for humans. In Origen's view, God's choice to provide for us in an indirect way is itself a way of fostering the development of our human capacities. Were God to provide for us directly, by simply placing food in our hands every day and meeting all of our needs, we would not be driven to garden, to care for livestock, to build, to create art, to invent, to philosophize. God "created man a being full of wants," Origen tells us, and accordingly placed us within a system where our capacities would be realized only through a process of fulfilling those wants. He does not do so for the irrational animals, who do not need to garden and who are given natural coverings such that they do not need to build shelter for themselves. And so the fact that he provides for us in this particular way 
(i.e., indirectly and inefficiently, such that we must work for our welfare) is precisely the proof that God has a special care for humans (Origen 1980, bk. IV 76).

What are we to make of Origen's suggestion? If God's providence manifests itself toward humans in this indirect and inefficient way, and if indeed this form of providence is purposefully oriented toward our good, then how exactly are we to understand that good? What is the nature of this good that God chooses for humans?

To answer these questions, we need to move from general providence into issues of special and redemptive providence. In the scriptural texts related to providence, we saw these varying "levels" of providence emerge, and we can see this again in the writings of various church fathers. Chrysostom, for example, expresses an idea similar to Origen's, where general providence is somehow especially suited for meeting human needs, both natural and spiritual:

$\mathrm{He}$ created this praiseworthy and all-harmonious universe for no one else but you. For your sake he formed it so beautiful and so great, diverse, costly, completely sufficient for every need, useful, profitable in every way, apt for the sustenance and formation of the body, the growth of the spiritual life, and as a pathway toward the knowledge of God. (Hall 1991, 221)

But what does it mean, specifically, for the world to be created for the sake of human spiritual growth and knowledge of God?

The present life is a wrestling school, a gymnasium, a battle, a smelting furnace, and a dyer's house of virtue. Therefore, just as tanners grasp the hides and first work them vigorously, stretching, striking, and dashing them against walls and rocks, and by countless other treatments render them fit for the reception of the dye-in this way they bring out the prized color; just as goldsmiths throw the gold into the fire to purify it, delivering it over to the testing of the furnace; just as coaches train the athletes in the wrestling schools with much hard work, attacking them more viciously than their opponents, so that every part of their bodies might be adequately prepared by exercise for the grasps of their enemies and for an easy escape; so in the same way God acts in the present life. Desiring to transform the soul into a serviceable condition for virtue, he works it, melts it, and delivers it over to testing of trials, in order to strengthen those who have lost heart and who 
have let themselves go, in order that those who have already been tested might be even more approved and unconquered by the plots of the demons and the snares of the devil, completely worthy for the reception of the good things to come. (Hall 1991, 366-67)

Chrysostom describes God as active in this process of salvation, redemptive providence, whereby God makes use of the trials and tribulations of this life to transform and redeem the Christian who undergoes the process.

\subsection{What About Randomness?}

I have now described most of the core ideas concerning God's providence that emerged over the first five centuries of Christianity. On the Christian understanding, God's providence is oriented toward a hierarchy of goods for creation: at the lowest level, the regular and orderly operation of the cosmos; at an intermediate level, the health and well-being of living creatures; and at the highest level, the salvation of human individuals. I have avoided one complicating issue: randomness. (Apparently) random events seem to present a challenge to the notion of providence. God's plan for providing this hierarchy of goods seems to require a certain degree of control, and randomness seems to oppose control.

\subsubsection{Grappling with Preexisting Thought}

Before discussing randomness and providence, we need to acknowledge the everyday phenomena that all people (Christian or otherwise, theist or otherwise) must grapple with. On the one hand, there is much in the world that is stunningly orderly and predictable. In the sky we see the stars and planets orbit with the utmost regularity; on the earth, biological organisms of every kind produce marvelous and intricate structures. On the other hand, apparently random occurrences present themselves as stark contrasts to order: leaves fall from trees every which way, with no obviously predetermined destination; a young child is unpredictably struck with cancer; a tornado spontaneously forms with little warning.

Since order and chance are obvious and seemingly contradictory, the dueling pair stands in need of explanation. The ancient Greeks and Romans grappled extensively with the problem. Popular explanations came from poetry and myth: unpredictable Tyche, goddess of chance and fortune, visited her whims upon the world, while the Moirai (the fates), who 
determined human destinies, established order and purpose. Both order and chance existed side by side in a world ruled by whimsical gods or forces. Plato, on the other hand, told a story of a Divine craftsman, the Demiurge, forming the world out of chaotic preexisting matter, in imitation of a perfect eternal realm. Thus, Plato attributed the order in the world to the Demiurge and the eternal realm that served as a model, while random and disorderly events were attributed to the recalcitrant material that the Demiurge was constrained to work with. Later Stoic philosophers argued that chance is illusory; the world is governed and determined by a divine order that is immanent in the world; the appearance of chance was the result of causes that were not understood. ${ }^{4}$

Early Christians grappled with this explanatory challenge against this backdrop of thought: how to reconcile God's creation in which order and randomness exist side by side, and how to explain how God can carry out his plan despite the random features of the world. In contrast to Plato's proposal of a Demiurge who shapes preexisting matter, Christians held that God created the universe ex nibilo (out of nothing), not out of preexisting matter. Since they could not attribute chance happenings to the chaotic and recalcitrant nature of matter, Christians found it difficult to explain chance as a phenomenon. After all, if God was not constrained by preexisting recalcitrant matter, why would God create matter with such recalcitrant properties? Could he not have created a more docile matter that naturally fell into order? If randomness is real, it would have to be part of God's design.

Some would reject genuine randomness. Perhaps events that appear to be random are actually determined and ordered at some imperceptible level. Perhaps a person's heart attack, even if it appears random, is actually the result of a series of hidden but determinate causes. Some Christians sympathized with this sort of a Stoic proposal. St. Augustine of Hippo, who was influenced by Stoicism, took something like this position.

\subsubsection{The Augustinian Model of Providence}

Augustine rejected the view that the earthly realm (as opposed to the celestial realm of the stars and planets) is subject to "the sport of chance and fortuitous motion." He responds to this philosophical view by introducing a commentary on Psalm 148:7-8.

${ }^{4}$ See (Miller 2016). 
Praise the Lord from the earth, monsters of the sea and all the deeps, fire, hail, snow, and ice, and storm winds fulfilling His command.

Nothing seems to be so much driven by chance as the turbulence and storms by which these lower regions of the heavens (rightly included also under the term "earth") are assaulted and buffeted. But when the Psalmist added the phrase, fulfilling His command, he made it quite clear that the plan in these phenomena subject to God's command is hidden from us rather than that it is lacking to universal nature. (Augustine 1982, 175)

Augustine believes that chance is incompatible with nature's being subject to God's command; apparently "chancy" phenomena are ruled by a plan of God that is hidden from us. After all, there are many places where God's plan and providence are obvious:

What more absurd or foolish opinion can be maintained, therefore, than to hold that the will of God and the ruling power of HIs providence are lacking in that whole region whose lowliest and smallest creatures are obviously fashioned by such a remarkable plan that a moment's serious attention to them fills the beholder with inexpressible awe and wonder? (Augustine 1982,175 )

But what does it mean for the world to fulfill God's command or follow his plan? In the chapter immediately following the above passages, Augustine argues there is a sort of finality inherent in God's creative act “in the beginning." But God's creative act is also gradual and continuous. He uses the analogy of a seed.

In the seed ... there was invisibly present all that would develop in time into a tree. And in this same way we must picture the world, when God made all things together, as having had all things together which were made in it and with it when the day was made. (Augustine 1982, 175)

So God's initial creative act, like the planting of a seed, instills God's plan into the world. (In fact, Augustine thinks of the six "days" of creation not as a succession of periods of time, but rather as the causal plans that he has established within the universe.) But there is more to God's creative act: 
he continues to bring forth the metaphorical fruit over time. Just as a seed gradually grows into a tree, which in turn produces fruit, so the initial creative act of God instills in the world a set of causal plans that gradually give rise to all manner of goods: stars and planets, land and water, plants and animals, humans.

Augustine's view is not unlike Stoic determinism. There is a hidden plan that is responsible for all things, even when those things appear random. And while the transcendent Christian God differs from the immanent Stoic God, Augustine retains a strong sense of immanence. This seems to be an appropriate way of understanding the creative act of the God of Jesus Christ, who is both transcendent and immanent.

But puzzles remain with the Augustinian view.

Firstly, Augustine's seed-model need not be deterministic. Couldn't the natural tendencies implanted as seeds in creation be, well, tendencies that sometimes, but don't always, produce a certain result? For example, a hen might tend to lay an egg daily, but that doesn't mean that she will every day. Seeds of creation, so it seems, might evolve in "chancy" ways.

Secondly, it's not clear how God's causation relates to the natural causation of "seeds" on Augustine's model. If an efficacious (and deterministic) causal power is planted within creation itself, God needn't continually act and bring forth. Why couldn't he-or why doesn't he-just sit back and let creation act as it is wont to do? The model sounds like a case of "overdetermination," as it is called in contemporary philosophy. The setup seems redundant.

But perhaps that's the point. Perhaps it is redundant, because God isn't concerned with efficiency. Perhaps God simply wants to be present in the world in an intimate and causal way. Such a desire would be consistent with his overabundant love for creation, after all.

This ambiguity in Augustine's ideas becomes a locus for later Christian reflection.

\subsubsection{Enter Aristotelianism}

While Platonism and Stoicism exerted influence on Christian thought, many classical Greek texts, including the majority of Aristotle's writings, were lost to Christian Europe throughout most of the medieval period. During this period, Islam's so-called Golden Age of intellectual and 
technological flourishing found Muslim scholars studying and commenting extensively on many Ancient Greek texts, including Aristotle's works. Through the Islamic world a Christian Europe "rediscovered" Aristotle. From the mid-twelfth to mid-thirteenth centuries, many texts and their Islamic commentaries were gradually translated from Arabic into Latin. This became a momentous occasion for the development of Christian thought, particularly on the subject of God's causal relation to nature.

The most famous Christian thinker to engage with these new texts was Thomas Aquinas. I will focus on the aspects of his thought that are most relevant to providence and randomness. In the context of an interfaith book, it is worth noting that Aquinas was heavily influenced by the Muslim philosopher Ibn Rushd and the Jewish philosopher Maimonides.

Recall that, in our examination of Augustine's model of creation in the last section, we came to a puzzle over how God's causal power relates to the natural causal powers within creation. In particular, it seemed that the two causal powers were redundant, and that one or the other might be entirely superfluous. Aquinas developed an answer to this puzzle.

On Aquinas' view, every agent in the natural world has certain powers inherent to it because of the kind of thing it is. For example, fire has the power to heat and to burn, and a knife has the power to cut. However, just as every created being owes its existence to God, every created being also owes its causal powers to God. In other words, God's creative act is so powerful that it does more than simply bring a thing into being-it also imbues that thing with certain powers.

Therefore, God causes each action inasmuch as he bestows the power to act, preserves it, and applies it to action, and inasmuch as every other power acts by his power. (Aquinas 2012, 58)

This is Aquinas' well-known teaching on primary and secondary causation. God is a primary cause of all of creation. Primary causation is creative causation; it is the power by which God gives existence and essence to all created things, including all of the causal powers inherent in those created things. The powers granted by God are called secondary causes, the causes built into creation itself. 
But why the redundancy, when God could do things more simply by causing everything directly? According to Aquinas:

Nor is it superfluous, even if God can by Himself produce all natural effects, for them to be produced by certain other causes. For this is not a result of the inadequacy of divine power, but of the immensity of His goodness, whereby $\mathrm{He}$ has willed to communicate His likeness to things, not only so that they might exist, but also that they might be causes for other things. (Aquinas 1991, sec. III.70.7)

God gifted his creatures with their own causal efficacy. As such, God relinquished some control over the exact results of that empowerment. Since God chooses not to "exclude from things the power of falling from the good," (Aquinas 1991, sec. III.71.3) God does not always prevent evil and corruption from occurring (possible consequences of the causal power he has granted to created things).

What about chance? Just as God does not prevent all evil from occurring, he likewise does not exclude contingency and chanciness from creation (Aquinas 1991, sec. III.72.1). Aquinas holds that chance events are possible because of creaturely limitations. Creatures control and determine their effects in varying degrees, and when their causal powers intersect, their effects may not be determined or intended (Aquinas 1991, sec. III.74.4-6).

Aquinas wrestles with the compatibility of chance with providence:

Either, then, we must say that not all effects are subject to divine providence and, thus, that providence does not apply to all — but we showed earlier that it does; or else it is not necessarily so, that, granted providence, its effect must be granted, and thus providence is not certain; or, finally, it is necessary for all things to happen by necessity. For providence is not only in present or past time, but in eternity, since nothing can be in God that is not eternal. (Aquinas 1975, sec. III.94.3)

But Aquinas makes a startling claim: it is good that God has created creatures that are contingent in their action. He goes on to say: "It would be contrary to the meaning of providence, and to the perfection of things, if 
there were no chance events" (Aquinas 1991, sec. III.74.3). How could it possibly be contrary to providence for there to be no chance events? This puzzling assertion is worthy of consideration.

Aquinas' argument relies on his understanding of contingency: since contingency is contrary to necessity, something with no contingency would be necessary and incorruptible. A world without contingency would be a world without generation and corruption, birth and death, or any type of change, including motion. Such a world would be terrible, one that God would never will into being (Aquinas 1991, sec. III.72.4-6).

The reason that Aquinas thinks this way lies deep in the foundation of his philosophy. Aquinas holds that action follows being. This principle states that the behavior of a thing is always grounded in what it is; the essence of a thing determines the scope of possible actions and behaviors. Therefore, a contingent being is bound to act in contingent ways, and a being that does not act in contingent ways would not be a contingent being.

Those who are not convinced by this principle-and I admit to being one of them-may not find Aquinas' reasoning here altogether convincing. There seems to be nothing logically contradictory in the idea of a created thing being contingent - that is, radically dependent on God for its existence-while also having a temporal tendency to change. A lack of contingency does not have to preclude change. Moreover, it seems perfectly possible for a being to change, albeit in perfectly predictable and deterministic ways that are not subject to chance.

But might there be another way to defend Aquinas' claim that God's providence wills that there be chance in creation? I think there is, but it requires stretching a bit beyond Aquinas' thought.

\subsubsection{Modern Science}

Christians were wrestling with issues of chance and providence long before the advent of modern science, with a great deal of openness to the possibility of randomness in the world. But in the early modern period, with new scientific theories like those of Galileo, Boyle, and Newton, it seemed that more and more of the world could be explained through mathematical laws; randomness looked increasingly like an illusion that would be explained away with enough detailed information about the world. In one of the most grandiose moments of deterministic theorizing, Laplace hypothesized: 
We ought then to regard the present state of the universe as the effect of its anterior state and as the cause of the one which is to follow. Given for one instant an intelligence which could comprehend all the forces by which nature is animated and the respective situation of the beings who compose it an intelligence sufficiently vast to submit these data to analysis it would embrace in the same formula the movements of the greatest bodies of the universe and those of the lightest atom; for it, nothing would be uncertain and the future, as the past, would be present to its eyes. (Laplace [1814] 1902,4)

This god-like intelligence (later called "Laplace's Demon") symbolized the idea of complete predictability and deterministic causation. Intellectuals (including Christian thinkers) increasingly accepted a mechanistic and deterministic worldview. A single formula that governed everything in the world seemed just a matter of time.

Many Christian thinkers used the mechanistic and deterministic worldview as evidence of God's design and craftsmanship. Perhaps providence and randomness was a non-issue. Yet other problems lurked. The new worldview left little room for free will, and the problem of evil appeared to have worsened. For evil could not be an artifact of chance, but rather part of the predetermined design of God. A variety of "solutions"-from predestination to occasionalism- to these problems were proposed. ${ }^{5}$

In 1859, randomness dramatically re-entered scientific conversation with the publication of Charles Darwin's On the Origin of Species. Darwin proposed that chance was at the heart of biological forms and their history. Random variation in the characteristics of organisms, when paired with natural selection, explains the gradual changes that were apparent in the various patterns of biological diversity. His idea was controversial but compelling, and over the next century, as more details about inheritance were discovered, culminating in the discovery of the structure of DNA, evolution by natural selection became widely accepted by the scientific community.

Modern scientific theory also revived the problem of randomness through quantum mechanics. ${ }^{6}$ Quantum mechanics emerged from a number of puzzling discoveries in the late nineteenth and early twentieth

${ }^{5}$ For more on this topic, see (Brooke 2016).

${ }^{6}$ There were other theoretical affirmations of randomness, including chaos theory and the statistical foundations of thermodynamics. Here I concentrate on the two most prominent loci in which modern scientific theories involved randomness. 
centuries. It is currently our best physical theory for describing the energy and movement of systems at the smallest scale of atomic and subatomic particles. According to the theory, Laplace's thought experiment is wrong: the complete description of a given physical system does not determine a specific outcome. It can give us only a set of possibilities and probabilities, not a specific certain outcome. Unless scientists are mistaken, the world is ontologically random. ${ }^{7}$ We can no longer determine what specific event will evolve from another.

Are these theories a problem for a Christian understanding of providence? Many modern Christians have thought so. Christian reactions to Darwin's theory in particular were negative. While some objections pertained to interpretation of the creation story in Genesis, others pertain to our topic here, rejecting the role of chance in Darwin's theory. What could random variations (or "mutations"), which provide the raw material on which natural selection acts, mean for God's plan? How could God have a plan for the world-a plan that culminated in human beings-yet leave the basic mechanism up to chance? With respect to quantum theory, how could God govern everything else if there is indeterminism at the most fundamental level of the world?

For Christian intellectuals who had become accustomed to a deterministic vision of the world and a narrowed notion of providence that required God's complete control over every event, the chanciness of this scientific picture was hard to swallow.

\subsection{A Possible Solution}

My goal in covering this sweeping history has been to give a broader context for the questions that modern Christians ask about God's providence and its relation to scientific randomness. Within this broader context, these questions are not new. They may have taken a new form, often expressed in technical and scientific language, but they are not new. These are not easy problems; they are not and never were easy to solve. But modern Christians can take some comfort in the fact that we are confronted

\footnotetext{
${ }^{7}$ This appears to be a strong possibility. Even if there is a hidden variable that renders the evolution of a quantum system deterministic, it has been proven that the hidden variable would have to be nonlocal, meaning that it violates the strongly-held principle of spatiotemporal locality. Such a hidden variable would require a revision of other fundamental theories, in particular the General Theory of Relativity.
} 
with the same difficulties as Christians of every era; we have not encountered a new and unprecedented problem. And we can make use of the thought of earlier Christians as we confront the problem in our own historical time.

What is that age-old problem? Simply put, it is the question of how God can be provident over his creation while also relinquishing some control over it and allowing it to run its course in ways that are sometimes random. If God wills certain specific events to occur, and wills the good of his creatures, how can he relinquish control? How can he allow randomness to affect the course of events?

There are many ways of thinking about this problem and responding to it. Some are more satisfying than others, and individual Christians are bound to disagree, as there is much mystery in God's intentions and our speculations are bound to get things wrong. But to conclude this chapter, I will now propose my way of thinking about this problem. To do so, I will highlight various points that I have mentioned earlier in the chapter and try to weave them together.

1. God sees it as a great good for creatures to have a kind of autonomy in their own actions. Contingency (chanciness) of action is one manifestation of this autonomy. Just as God grants to humans free will, he grants to all creatures analogous degrees of autonomy. This extends all the way down to subatomic particles. (Subatomic particles do not have wills or intentions, but the analogy holds: their possibilities for behaving this way or that are genuine possibilities, and God allows their inherent indeterminism rather than impose his own outcome.) God is that generous with creation, through and through. ${ }^{8}$

2. From his eternal perspective, God can love and foreknow every detail about an individual human being (i.e., you or me). But that he loves and foreknows a person does not require that he controls every single event that led up to that person's existence and subsequent development. Again, he loves creation that much, to grant it some autonomy.

3. God allows evil things to happen in the world. This is consistent with the autonomy that he bestows on creation and the randomness that he allows to be a part of the causal structure of creation. The tradition of

${ }^{8}$ This point is inspired by Aquinas and his robust belief in secondary causation, but I have taken Aquinas' thought a bit further than he himself might like. He might object to the degree of indeterminism in the inanimate world that I suggest here. 
Christian spiritual practices also presumes that he does choose to prevent some evils, according to his wisdom. We don't have any way of knowing how many evils he chooses to prevent or his specific criteria for doing so. However, redemptive providence is his utmost form of care for creation. And because salvation/redemption is a more important good than other transient goods, there are evil events that he allows creatures to endure in working out their redemption.

4. The Christian message consistently affirms that the means of our salvation is directly tied up with suffering. Jesus' death on the cross is the means of our salvation and furthermore, we are to emulate him by offering up our own sufferings. That a certain degree of randomness is inherent in creation is not only consistent with God's redemptive providence, but conducive to it. The struggle with a world that is sometimes random and unpredictable is an efficacious means of our coming to know God more deeply and be transformed in his image. God wills for us a life that is a "wrestling school" like the one that Chrysostom describes, as it brings about our redemption.

Therefore, my beloved, as you have always obeyed, so now, not only as in my presence but much more in my absence, work out your own salvation with fear and trembling; for God is at work in you, both to will and to work for his good pleasure. (Philippians 2:12-13)

\section{BIBLIOGRAPHY}

Aquinas, Thomas. 1975. Summa Contra Gentiles: Providence, Book 3 Part 2. Translated by Vernon J Bourke. London: University of Notre Dame Press.

- 1991. Summa Contra Gentiles: Providence, Book 3 Part 1. Translated by Vernon J. Bourke. South Bend: University of Notre Dame Press.

- 2012. The Power of God. Translated by Richard J. Regan. New York: Oxford University Press.

Augustine. 1982. The Literal Meaning of Genesis. Translated by John Hammond Taylor. Ancient Christian Writers. New York: Newman Press.

Brooke, John Hedley. 2016. Divine Providence in the Clockwork Universe. In Abraham's Dice, ed. Karl W. Giberson, 215-239. New York: Oxford University Press. https://doi.org/10.1093/acprof:oso/9780190277154.003.0011.

Hall, Christopher Alan. 1991. John Chrysostom's 'On Providence': A Translation and Theological Interpretation. Drew University. https://www.proquest.com/ docview/303944123 
Laplace, Pierre Simon. (1814) 1902. A Philosophical Essay on Probabilities. Translated by F.W. Truscott and F.L. Emory. New York: Wiley.

Miller, Richard W. 2016. Chance and Providence in Early Christianity. In Abraham's Dice, ed. Karl W. Giberson, 129-157. New York: Oxford University Press. https://doi.org/10.1093/acprof:oso/9780190277154.003.0007.

Origen. 1980. Contra Celsum. Translated by Henry Chadwick. New York: Cambridge University Press.

Theodoret. 1988. On Divine Providence. Translated by Thomas P. Halton. Ancient Christian Writers 49. New York: Newman Press.

Open Access This chapter is licensed under the terms of the Creative Commons Attribution 4.0 International License (http://creativecommons.org/licenses/ by $/ 4.0 /$ ), which permits use, sharing, adaptation, distribution and reproduction in any medium or format, as long as you give appropriate credit to the original author(s) and the source, provide a link to the Creative Commons licence and indicate if changes were made.

The images or other third party material in this chapter are included in the chapter's Creative Commons licence, unless indicated otherwise in a credit line to the material. If material is not included in the chapter's Creative Commons licence and your intended use is not permitted by statutory regulation or exceeds the permitted use, you will need to obtain permission directly from the copyright holder.

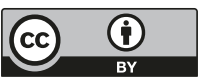

